\title{
Garderoba polskich elegantek w XVIII wieku
}

Moda jest naśladowaniem innych, identyfikowaniem się z grupą społeczną i sposobem wyrażania siebie. Wszechobecna moda wiąże się ze stylem życia, zachowaniem, światopoglądem, a w węższym znaczeniu projektowaniem ubioru. Moda ma swoje uzależnienie od klimatu, warunków gospodarczych, politycznych, ekonomicznych, od obyczajów, poziomu produkcji, religii i statusu społecznego. Ubiór, zwłaszcza w przeszłości, świadczył w znacznej mierze o zamożności i pozycji w społeczeństwie. Był oznaką przynależności do danej warstwy społecznej.

Tak jak w innych czasach, tak i w XVIII wieku przywiązywano dużą wagę do wyglądu zewnętrznego.

(...) występowała tendencja ukazywania się w najpiękniejszym, najmodniejszym stroju. Strój, wygląd zewnętrzny, był symbolicznym biletem wizytowym ówczesnych ludzi, miał uosabiać dobry gust, bogactwo, pozycję społeczną. Ówczesne pojęcie piękna stroju było odmienne od obowiązującego dzisiaj, we wszystkich prawie odmianach mody i rodzajach strojów uderza ich barwność i jaskrawość. Lubowano się w mocnych barwach, żółtych, błękitnych, pomarańczowych, zielonych. Moda nakazywała też, by strój zawierał maksymalną ilość ozdób, kosztowności ${ }^{1}$.

Poprzez analizę stroju postaram się wskazać, jak moda wpływała na gusty zamożnych kobiet. W moim artykule opisuję różne rodzaje damskich ubiorów oraz ich ozdobne elementy i dodatki, jak również tkaniny, z których zostały uszyte.

\section{Tkaniny}

Osiemnastowieczne stroje szyto z przepięknych tkanin. Damy miały do wyboru całą paletę barw i ogromne urozmaicenie faktur. Tkaniny odzieżowe były wytwarzane w warszatach rzemieślniczych i zakładach przemysłowych. Wyroby

\footnotetext{
1 Z. Kuchowicz, Obyczaje staropolskie XVII-XVIII wieku, Łódź 1975, s. 225.
} 
przemysłu krajowego uzupełniały towary importowane. Krajową bazę surowcową stanowiła produkcja włókiennicza sukna, tkanin półwełnianych, płótna, wyrobów bawełnianych, jedwabnych, półjedwabnych, filców, wstążek, dzianin, pasmanterii, a także koronek.

Polska w drugiej połowie XVII i na początku XVIII wieku, pogrążona w konfliktach wojennych, borykała się z zubożeniem i zniszczeniami. Odbiło to swoje piętno także na produkcji wyrobów włókienniczych i w konsekwencji spowodowało upadek tego rzemiosła. Ta niekorzystna sytuacja utrzymywała się do połowy XVIII wieku. W tym okresie wyroby tekstylne i galanteryjne lepszego gatunku importowano. Częściową przyczyną ubożenia cechów kuśnierskich było też przejmowanie przez kupców żydowskich futer importowanych z Rosji. Wszak od połowy XVIII wieku na ziemiach polskich istniały manufaktury sukiennicze m.in. w Skierniewicach ${ }^{2}$, Nieświeżu ${ }^{3}, S^{\prime}$ ucku$^{4}$, Tarnowcu i Kidałowicach; natomiast produkcja włókiennicza miała miejsce w Warszawie i Golędzinowie, a z kolei manufaktury płócienne znajdowały się np. w Lowiczus.

W modzie ceniono czapki z opuszką futrzaną. Kuśnierze zajmowali się również farbowaniem skór i łączeniem ich w błamy. „Farbowano szlachetne skórki dla podniesienia ich wartości handlowej, a tańsze - w celu uzyskania imitacji najdroższych futer. Farbowano szeregiem barwników mineralnych i roślinnych"6. Na rynku kuśnierskim do wyboru były skóry futerkowe z lisów, baranów, wilków i wydr. Liczba miechowników zajmujących się szyciem produktów z miękkich skór zamszowych, safianowych lub kurdybanowych stopniowo się zmniejszała.

Fragmentaryczne dane świadczą o „wygasaniu” części zawodów kuśnierskich i przekwalifikowaniu się rzemieślników. Z rynku rzemieślniczego zniknęli miechownicy, a ich obowiązki odziedziczyli rękawicznicy?

Osiemnastowieczne magnatki chętnie angażowały się w działalność gospodarczą. Dobrze wykształcone, przedsiębiorcze i pracowite niejednokrotnie odnosiły sukcesy w tej dziedzinie. Trzeba nadmienić, iż magnatki często odziedziczały manufaktury po swoich małżonkach i z powodzeniem zarządzały nimi. Warto wspomnieć o operatywnej Annie Katarzynie z Sanguszków księżnej Radziwiłłowej. Kanclerzyna wielka litewska była kobietą wyjątkowo zaradną i niezwykle

2 J. Józefecki, Manufaktura sukiennicza w Skierniewicach w latach 1786-1795, „Mazowieckie Studia Humanistyczne", 1997, nr 1, s. 227.

3 A. Jezierski, C. Leszczyńska, Historia gospodarcza Polski, Warszawa 2003, s. 80.

4 W. Kula, Szkice o manufakturach w Polsce XVIII wieku: 1720-1764, Warszawa 1956, s. 36.

5 Zarys historii włókiennictwa na ziemiach polskich do końca XVIII wieku, (red.) J. Kamińska, I. Turnau, Wrocław-Warszawa-Kraków 1966, s. 313-415.

6 I. Turnau, Rzemiosta włókiennicze, odzieżowe i skórnicze 1655-1795, [w:] Z dziejów rzemiosła warszawskiego, (red.) B. Grochulska, W. Pruss, Warszawa 1983, s. 203.

7 Ibidem, s. 174. 
zorganizowaną. Po śmierci męża Karola Stanisława Radziwiłła w 1719 roku zamieszkała w Białej i zaczęła energicznie zarządzać rozległymi dobrami, a także zainteresowała się działalnością gospodarczą. Z jej inicjatywy powstały m.in. manufaktury włókiennicze działające od 1737 roku: sukienne w Białej i Słucku. Księżna utworzyła w Białej również hafciarnię\&.

Rozwój przemysłu tekstylnego na naszych ziemiach możemy zaobserwować w organizowanych manufakturach od ok. połowy XVIII wieku. Po 1750 roku manufaktury włókiennicze zakładano przede wszystkim w majątkach magnackich. Ich priorytetem był wyrób produktów luksusowych.

(...) manufaktura sukiennicza wyrabiała ,sajety” o jedwabistym połysku w modnych odcieniach, tonacji popielatej od jasnej perłowej do niebieskoszarej, ,,makowej”, dużej skali innych barw, nawet intensywnej czerwonej w odcieniu karmazynu i gorącej czerwieni cynobru. Na sukna doborowe używano wełny zagranicznej i runa polskich owiec rasowych ${ }^{9}$.

W grodzieńskiej manufakturze jedwabniczej podążającej za wzorami francuskimi i wiedeńskimi powstawały lekkie tkaniny jedwabne, tafty w paski i prążki z niewielkimi rzutami ornamentu srebrnego. Produkowano tam również ciężkie lamy złote i srebrne, m.in. na balowe kobiece robrony (balowa suknia dworska z ciężkich tkanin jedwabnych, o konstrukcji kloszowej). Tkaniny jedwabne także w dużej części były importowane. Jedwab o lepszej gatunkowo jakości był kosztowny. Najwyżej cenione były jedwabie francuskie, tzw. lyońskie. Suknie na wielkie wyjścia szyto $\mathrm{z}$ jedwabnych tkanin o rewelacyjnych wzorach. Jedwabne materiały przeznaczone na kobiece suknie przeważnie były broszowane, tzn. wzory osiągano w procesie tkania przez dodanie kilku kolorowych wątków, co z pewnej odległości przypominało haft. Barwy wątków dekoracyjnych w materiale tkackim najczęściej się powtarzały. Zazwyczaj używano trzech odcieni jednego koloru, którymi stopniowano poziom nasycenia barwy. Wykorzystywano do tego trzy odcienie, np. koloru różowego - od jasnego bladoróżowego do krwistej czerwieni. Suknie magnatek i szlachcianek szyte były z materiałów jedwabnych, m.in. niebieskich, różowych, zielonych, wzorzystych, jak i gładkich, tkanych w pasy barwnych wijących się łodyg bądź wstęg i rozrzuconych między nimi kolorowych kwiatów ${ }^{10}$.

Wadą rodzimych tkanin była niewystarczająca liczba proponowanych wzorów. Powodowało to brak zainteresowania wybrednych szlachcianek krajowymi

8 K. Kolenda-Korczakowa, Działalność ekonomiczna Anny z Sanguszków Radziwiłtowej - manufaktury hafciarskie $w$ świetle nowych znalezisk, [w:] Dwory magnackie w XVIII wieku. Rola i znaczenie kulturowe, (red.) T. Kostkiewiczowa, A. Roćko, Warszawa 2005, s. 193, 195.

9 M. Gutkowska-Rychlewska, Historia ubiorów, Wrocław 1968, s. 709.

10 E. Szyller, Historia ubiorów, Warszawa 1963, s. 159. 
materiałami. Na terenie Polski powstawały również lżejsze tkaniny wełniane. Ponadto, importowano kamlot brukselski i wiele lekkich tkanin wełnianych, gładkich, tudzież wzorzystych z motywami geometrycznymi. „Przy rozpatrywaniu zagadnienia różnych rodzajów tkanin wełnianych noszonych w Polsce w XVIII wieku uderza przede wszystkim rozpiętość pomiędzy olbrzymią ilością nazw sukien i innych tkanin wełnianych" ${ }^{11}$. Importowano znaczne ilości sukna potrzebnego na cieplejszą odzież. Do Polski sprowadzano tkaniny z fabryk pruskich i austriackich, ale najbardziej ceniono materiały francuskie, gdyż to właśnie Paryż był stolicą mody europejskiej. Pracownie pruskich manufaktur zaopatrywały rynek polski w sporą ilość dobrego sukna, wyrabianego na wzór angielski. Warszawskie sklepy tekstylne posiadały w sprzedaży ekskluzywny towar. W latach dziewięćdziesiątych XVIII wieku w asortymencie sklepów warszawskich modniarek, które od początku tego wieku odznaczały się ekstrawaganckimi kreacjami, nie mogło zabraknąć modnych, lekkich gaz angielskich, muślinów, jak również wstążek do zdobienia kapeluszy i kobiecych sukni ${ }^{12}$.

W XVIII wieku zmieniała się moda na desenie i wzory tkanin. Do szytych sukien dodawano nowe elementy dekoracyjne lub zmniejszano ich liczbę, albo zmieniano kompozycję. Na początku XVIII wieku modne były tkaniny o pokaźnych wzorach i intensywnej barwie. Następnie przyszedł czas na jedwabne o koronkowych wzorach. Raporty (powtarzająca się jednostka wzoru na tkaninie) na tych tkaninach były symetryczne, a motyw koronki występował na całej szerokości brytu. W drugiej połowie XVIII wieku przeważały motywy roślinne takie, jak: gałązki, kwiaty, girlandy. W późniejszym czasie dodano pomiędzy wspomniane motywy wzory w postaci pasków i wstążek.

Poniżej przedstawiam kilka przykładów cen materiałów odzieżowych w XVIII wieku w Polsce. Na początku tego stulecia cena za 1 łokieć sukna szarego wynosiła ok. 20 groszy, a od roku 1775 jego cena wzrosła do blisko 60 groszy. Za 1 łokieć sukna „Düffel” (wąskie białe) trzeba było zapłacić ok. 10 groszy, a od 1775 roku prawie 20 groszy. Natomiast cena płótna białego w ciągu stulecia wahała się od 5,50 do 13,50 groszy za 1 łokieć. Na początku stulecia 1 łokieć płótna bawełnianego kosztował ponad 20 groszy, a po 1761 roku jego cena stopniowo wzrastała i wynosiła ponad 40 groszy. Do lat sześćdziesiątych XVIII wieku 1 funt wełny wyborowej kosztował ok. 2 złotych, a od 1761 blisko 3,50 złotych. Z kolei para trzewików kosztowała ok. 3 złotych, a cena pończoch wahała się w granicach od ok. 17 do 67 groszy za parę ${ }^{13}$.

11 I. Turnau, Zmiany w polskiej produkcji włókienniczej w XVIII wieku, Wrocław 1962, s. 220.

12 M. Gutkowska-Rychlewska, op. cit., s. 712.

13 Zainteresowanych szczegółowym wykazem cen odsyłam m.in. do pozycji: T. Furtak, Ceny w Gdańsku w latach 1701-1815, Lwów 1935, s. 159, 160, 164, 165, 169, 170, 172-174. 


\section{Bielizna i suknie}

Polskie elegantki w omawianym okresie naśladowały francuski i angielski styl ubioru i styl życia, a moda odgrywała tu ważną rolę.

Gdybyśmy zechcieli wybierać miss elegancji polskiego oświecenia, wybór byłby zaiste trudny! Nigdy chyba nie było w Polsce tylu pięknych i strojnych pań. Pierwsze damy ówczesnej Rzeczypospolitej - Izabela z Poniatowskich Branicka, Izabela z Flemmingów Czartoryska, Izabela z Czartoryskich Lubomirska czy Helena z Przezdzieckich Radziwiłłowa - prześcigały się w nadążaniu za paryskimi nowinkami. Rywalizowały ze sobą w przepychu urządzania pałacowych wnętrz, sielankowości sentymentalnych ogrodów, liczbie kochanków i wytworności strojów. Najnowsze kreacje francuskie znane były Polkom już nie tylko z żurnalowych rycin ale i z autopsji - żony i córki najmożniejszych magnackich rodów często wojażowały za granicę i pałac wersalski był im niekiedy lepiej znany niż sale warszawskiego zamku' ${ }^{14}$.

W garderobie osiemnastowiecznych dam nie mogło zabraknąć gorsetów i owalnych rogówek, czyli ówczesnych „,narzędzi tortur,” nadających kształt sylwetce.

W garderobie niewieściej jawią się szczegóły zbyteczne: to gorset, jak pancerz uciskający kibić, ściągany do tchu utraty, to przydeptywany ustawicznie ogon sukni, tzw. rucho, to do ręki kobiecej moda wkłada wiejaczkę, czyli wachlarz wytworny, narzędzie kokieterii dam przez długie wieki ${ }^{15}$.

Skarbiec z modnymi ubraniami mieścił w sobie również szlafroczki, żakiety z koronkowymi angażantami, okrycia wierzchnie podbite futrem, suknie, a także dodatki: naszyjniki z pereł czy kosztownych kamieni, wachlarze, koronkowe czepeczki, kapelusze i mulety.

Polskim centrum mody była oczywiście bogata i wytworna Warszawa. Jak zauważył Hubert Vautrin:

Kobiet w stroju cudzoziemskim jest znacznie więcej niż mężczyzn i tak samo jak Francuzki, są one niewolnicami mody. Zaledwie powstaje nowy strój, rodzi się najdrobniejsza zmiana w przybraniu toalety, musi ona natychmiast trafić z krawieckim manekinem do Warszawy, a stąd na prowincję ${ }^{16}$.

14 A. Sieradzka, Żony modne: historia mody kobiecej od starożytności do wspótczesności, Warszawa 1993, s. 78.

15 Ł. Charewiczowa, Kobieta $w$ dawnej Polsce, Poznań 2002, s. 32.

16 H. Vautrin, Obserwator w Polsce, [w:] Polska stanisławowska w oczach cudzoziemców, oprac.

W. Zawadzki, t. 1, Warszawa 1963, s. 778. 
Cudzoziemscy podróżnicy w swoich pamiętnikach z entuzjazmem wspominali eleganckie Polki. Taką pozytywną opinię można znaleźć m.in. w wypowiedzi Fryderyka Schulza:

Kobiecego stroju podstawą jest francusko-angielska moda; szczegóły pomniejsze dodają Polki, z własnego smaku i wynalazku je czerpiąc. Ubranie głowy ma swą właściwość i odznacza się czymś pośrednim pomiędzy sztywnością francuską a naturalnością angielską, co bardzo wdzięcznie zdaje się Wschód przypominać. W tym względzie są panie niewyczerpane i obfite w wynalazki. Nawet w razach uroczystych galowym ubiorem, które wszędzie są sztywne i ciężkie, umieją nadać lekkość, powiewność, które miło w oczy wpadają. Umiejętnie też ubierają się w brylanty ${ }^{17}$.

Jak wynika z komentarza podróżnika, Polki czerpały z elementów mody francuskiej i angielskiej, ale także wprowadzały rodzime detale, które podnosiły wizualne walory stroju.

\section{Bielizna}

Trzeba podkreślić, że termin „bielizna” w osiemnastowiecznej nomenklaturze spisów majątkowych definiował nie tylko bieliznę osobistą, ale również obrusy, serwety czy pościel. Ja natomiast zajmę się wyłącznie opisem bielizny osobistej.

Rola bielizny jako części stroju zmieniała się wraz z upływem czasu. Było to związane z coraz większym oddziaływaniem mody zachodnioeuropejskiej, ze zmianami wyobrażeń dotyczących higieny i wygody oraz ze zmniejszaniem się roli samego bogactwa stroju jako głównej oznaki wysokiego statusu społecznego ${ }^{18}$.

Duże znaczenie ma kwestia pojawienia się stroju nocnego. Wcześniej ludzie kładli się spać albo w ubraniach codziennych, albo nago. Widok nagiego ciała był czymś naturalnym i powszednim. Z czasem pojawił się specjalny strój nocny, co wiązało się z wrażliwością na wszystko co dotyczyło ciała. Zmieniła się mentalność ludzi i pojawiło się uczucie wstydu odnośnie nagości, a także zanikała swoboda, $\mathrm{z}$ jaką ją pokazywano. W życie towarzyskie zostało wplecione wstawanie z łóżka oraz udawanie się na nocny odpoczynek. Koszula nocna ze względu na to, iż była ubiorem noszonym publicznie nabrała charakteru reprezentacyjnego ${ }^{19}$.

Uważam, że była ona częścią ubioru mniej wartościową niż odzież wierzchnia. Podstawową i najczęściej wymienianą w spisach inwentarzowych bielizną

17 F. Schulz, Podróże Inflantczyka z Rygi do Warszawy, [w:] Polska stanisławowska w oczach cudzoziemców, oprac. W. Zawadzki, t. 2, Warszawa 1963, s. 586

18 J. Dumanowski, Świat rzeczy szlachty wielkopolskiej w XVIII w., Toruń 2006, s. 206.

19 N. Elias, O procesie cywilizacji: analizy socjo- $i$ psychogenetyczne, Warszawa 2011, s. 232. 
była biała, długa i szeroka koszula $\mathrm{z}$ rękawami do łokcia i dekoltem ściąganym sznureczkiem. Wyrafinowana dama wstając po nocy z łóżka, zdejmowała nocną koszulkę tzw. domieszkę, czepeczek i cieplejszy kaftanik. Domieszkę szyto z cienkiego płótna holenderskiego, muślinu, dymy, batystu bądź rąbku lnianego; ponadto ozdabiano ją gazą, koronkami i haftem. Dzienna koszulka zakładana przez elegantki musiała być ozdobiona przy szyi i rękawach falbanami albo koronkami. Młode damy zazwyczaj nie zakładały majtek, pozostawiając ten rodzaj bielizny starszym pokoleniom. Materiałem, z którego szyto kobiece figi było płótno lub barchan ${ }^{20}$. Wśród bielizny w inwentarzach wymieniano koronki, chustki czy nakrycia głowy. Do bielizny zaliczała się także halka pod rogówkę. Na lato szyta z lekkich tkanin, a na zimę watowana i pikowana. Część bielizny stanowił gorset noszony pod dezabile. Był to sznurowany staniczek czasem usztywniony fiszbinami, odrobinę wygodniejszy od właściwego gorsetu. „W końcu XVIII w. gorsety zastąpiły »pasy kobiece do podpasywania«, które podkreślały podwyższony stan modnych sukien" ${ }^{21 .}$

\section{Szlafroki}

Bardzo popularnym ubiorem domowym od drugiej połowy XVIII wieku był szlafrok. Eleganckie szlachcianki posiadały dwie wersje tego ubioru: na przedpołudnie (tzw. negliż) i bardziej strojną odmianę na popołudnie. „Szlafrok, szlafroczek, nocna jakoby suknia, której używać zwykli, nim się spać położą, albo mając wstać z rana i pokąd się nie weźmie dziennego ubioru. Męskie i kobiece bywają szlafroki, letnie i zimowe"22. Przód takiego szlafroka był otwarty. Szlafrok Izabeli Czartoryskiej prezentował się bardzo wytwornie: „szlafrok izabelowy atłasowy ze spódnicą takiegoż atłasu, lisztwa wokoło szlafroka ptaszym kaczorowym futrem okładana, z plecionką z oliwkami srebrnymi [podłużnymi pasmanteryjnymi guzikami z metalowych nici - dop. M.P. ], cały taftą podszyty”23.

\section{Negliż}

Damy epoki stanisławowskiej witały nowy dzień między dziesiątą a jedenastą. Ubrane wyłącznie w cienką, zwiewną tkaninę, tzw. negliż bądź półubiór

\footnotetext{
20 A. Bardecka, I. Turnau, Życie codzienne $w$ Warszawie okresu oświecenia, Warszawa 1969, s. 125 .

21 Historia kultury materialnej Polski $w$ zarysie, oprac. zbiorowe pod red. W. Hensla i J. Pazdura, t. 4, Od połowy XVII do końca XVIII wieku, (red.) Z. Kamieńska i B. Baranowski, Wrocław 1978, s. 351 .

22 Ł. Gołębiowski, Ubiory w Polszcze od najdawniejszych czasów aż do chwil obecnych, Warszawa 1830, s. 243.

23 M. Możdżyńska-Nawotka, O modach i strojach, Wrocław 2002, s. 160.
} 
i zawiązaną na włosach białą, muślinową chusteczką, przyjmowały w łóżku albo przy toalecie swoich przyjaciół. W ten oto sposób strój nocny zaczął pełnić funkcje publiczne i kreować modę sypialnianą ${ }^{24}$.

Niejednokrotnie wyruszając do miasta na nieoficjalne okazje, jak śniadanie, spacer czy zakupy w sklepie, ubrane były w dezabilkę, czyli wygodną niezobowiązującą suknię domową lub poranną. Nie posiadała ona wcięcia w talii i była luźna. Dezabile dwuczęściowe elegantki zaczęły nosić po 1730 roku. Szyto je z półjedwabnych lub bawełnianych, lekkich tkanin. Strój ten składał się z szerokiej spódnicy i równie okazałej góry. Łukasz Gołębiowski tak opisał dezabilkę: „suknia atłasowa, materyalna lub inna gładka biała, z mniejszą wytwornością i nie tak strojno zrobiona. W niej poufalsze tylko przyjmowano osoby" 25 .

\section{Suknie}

Polskie elegantki zmieniały ubiór zależnie od pory dnia i okoliczności. W porze obiadowej między godziną trzecią a czwartą damy przyodziewały się w bardziej dostojne i paradne suknie. Natomiast późnym wieczorem między dziesiątą a jedenastą zasiadano do kolacji. Z wielką przyjemnością uczęszczano na spektakle teatralne bądź oddawano się rozrywkom bardziej aktywnym, jak bale czy reduty (bale maskowe) ${ }^{26}$.

Asortyment rynku odzieżowego obfitował w bogactwo krojów i nazw sukien. Modne elegantki miały do wyboru trzy podstawowe wersje ubioru. Pierwsza to dwuczęściowe kombinacje, ze stanika, żakietu albo kamizelki skomponowanej ze spódnicą. Kolejny wariant to suknia jednoczęściowa, która nie była odcinana w linii stanu i zamknięta z przodu. Ostatnia opcja to także suknia jednoczęściowa, ale otwarta, z rozcięciem z przodu spódnicy w kształcie odwróconego „V”. Suknię tę noszono ze spodnią z tej samej bądź innej tkaniny ${ }^{27}$.

Do lat sześćdziesiątych XVIII wieku w modzie dworskiej królowały suknie dwuczęściowe, które były łatwiejsze w wymodelowaniu. Wzór sukni stanowił stanik i obszerna spódnica. Niezwykle strojna i uroczysta była suknia dworska, tzw. roba. Suknię tworzył sznurowany z tyłu i dodatkowo usztywniony fiszbinami stanik (kabat), który pełnił także rolę gorsetu. Do tego zakładano spódnicę na rogówce i wierzchnią spódnicę otwartą z przodu, która była podpięta i drapowana na bokach albo podpinano pofałdowany tren $\mathrm{z}$ tyłu $\mathrm{w}$ okolicach talii ${ }^{28}$.

\footnotetext{
24 N. Elias, op. cit., s. 232.

25 Ł. Gołębiowski, op. cit., s. 143.

26 M. Możdżyńska-Nawotka, op. cit., s. 142-143.

27 Ibidem, s. 150.

28 Ibidem, s. 150.
} 
Damy zakładały ją na najbardziej uroczyste przyjęcia na dworze Augusta III. Jędrzej Kitowicz tak opisywał tę suknię: ,roba jest czarna suknia, krojem kabata dziecinnego z tyłu sznurowana, mająca rękawy po łokieć krótkie, od tegoż łokcia aż do ramienia koronkami białymi jak najprzedniejszymi bryzowane, z tyłu ogon długi, zamiatający pokoje"29.

W drugiej połowie XVIII wieku z Francji przyszła moda na suknie jednoczęściowe. Ze względu na drobne różnice w kroju nosiły one różne nazwy: szamerluki, manty, szusty i szlompry oraz robrony. Były one wcięte w stanie, długie z przodu do kostek, a z tyłu znacznie dłuższe, gdyż na całej długości pleców wszyty miały fałd tkaniny zwany ogonem. Ta część sukni była tak długa, iż zatrudniano paziów do noszenia jej za swoimi paniami ${ }^{30}$.

Innym równie efektownym rodzajem modnych sukni była deshabillé - lekka, wygodna suknia. Pojawiła się najpierw we Francji w okresie Regencji (1715 rok), a w Polsce od ok. 1740 roku i była modna do ok. 1770 roku. Oryginalną suknią była robe volante, która charakteryzowała się luźnym i nieodcinanym $\mathrm{w}$ pasie krojem. Posiadała fałdy z przodu i z tyłu sukni. Była bogato zdobiona falbanami. Noszono ją na okrągłej rogówce. W Polsce luźne dezabile (wolanty, saki) wzorowane były na francuskiej robe volante ${ }^{31}$. Zakładano te suknie na przechadzki czy wizyty u przyjaciół.

Suknia typu deshabillés wywodziła się z sukni domowej modnej w ostatnich latach panowania Ludwika XIV; była suknią typową dla okresu Regencji, przez długi czas noszoną jako ubiór codzienny. Miała luźny krój bez przecięcia w pasie oraz szerokie pionowe fałdy, zgrupowane z przodu i na plecach. Spod rękawów, zakończonych na wysokości łokcia rozszerzonym mankietem en pagode, wystawał rękaw koszuli ujęty w mankiet, zakończony płóciennymi i koronkowymi angażantami. Noszona wówczas niska fryzura z upiętych włosów przykryta była niewielkim, płaskim czepeczkiem ${ }^{32}$.

Do połowy XVIII wieku były modne saki wkładane przez głowę, rozkloszowane, $\mathrm{z}$ niewielkim pęknięciem pod szyją. Szyto je przeważnie z jedwabiu w pasiaste wzory i ozdabiano złotymi lub srebrnymi galonami ${ }^{33}$.

$\mathrm{W}$ drugiej połowie tego stulecia przyszła moda na robrony (fr. robe ronde okrągła suknia), czyli suknie z jedwabnych ciężkich tkanin noszone na okrągłej rogówce. Nie były one rozcięte z przodu. W Polsce do końca XVIII wieku były uważane za strój dworski i zakładane przez majętne damy na bale. Gołębiowski

\footnotetext{
29 J. Kitowicz, Opis obyczajów za panowania Augusta III, Warszawa 1985, s. 267.

30 Ibidem, s. 264.

31 M. Możdżyńska-Nawotka, op. cit., s. 153.

32 F. Boucher, Historia mody: dzieje ubiorów od czasów prehistorycznych do końca XX wieku, Warszawa 2012, s. 261.

33 M. Możdżyńska-Nawotka, op. cit., s. 153.
} 
Robe à la française

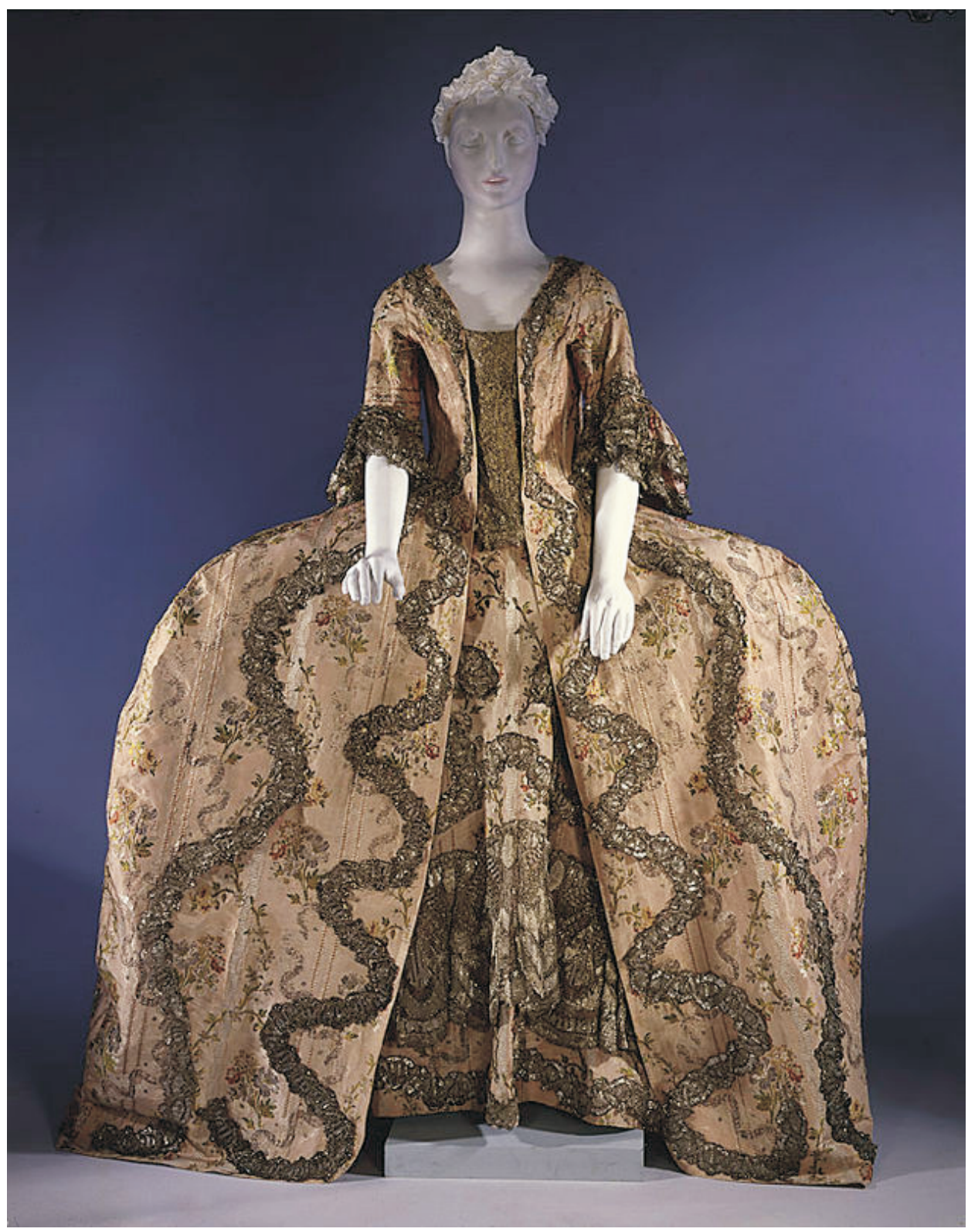

Suknia, 1764, Muzeum Narodowe w Warszawie.

Za zgodą Muzeum Narodowego w Warszawie. 
tak pisał o nich: „nader kosztowne bywały i z materyi tak tęgiej, że postawione zręcznie, utrzymać się mogły ich spodnice" 34 .

Jeszcze innym rodzajem ubioru, typowym w owym czasie, były suknie otwarte z przodu, przez co odsłaniały spodnią spódnicę. Początkowo robe manteau była wygodną suknią codzienną. Jej fason przypominał krojem kimono. $\mathrm{Z}$ przodu była rozcięta od góry do talii. Fałdy sukni spływały od ramion z przodu, jak i z tyłu. Nie była ona usztywniona fiszbinami, ale damy pod spód kreacji zakładały gorset. W XVIII wieku manteau przekształciła się w uroczystą suknię dworską, a jej wygląd się zmienił. Otwarty był stanik, a z tyłu długi tren, który fantazyjnie upinano. Rękawy sięgały do łokcia i wszywano je do wyciętej wysoko pachy. Kształt spódnicy dopasowano do rogówki ${ }^{35}$. „Niektóre modele miały stanik drapowany, a obszerne rękawy krój kimonowy. Przez większą część stulecia w modzie pozostawała odziedziczona po XVII wieku mantaua, rodzaj dopasowanej u góry sukni z drapowaną z tyłu spódnicą" ${ }^{36}$.

$\mathrm{W}$ drugiej połowie XVIII wieku robe à la française (suknia w stylu francuskim) wyparła robe manteau i robe z kabatem - ceremonialne suknie dworskie. Jednoczęściowa suknia francuska należała do kreacji najbardziej popularnych w osiemnastowiecznej modzie europejskiej. Na taką suknię trzeba było zużyć ponad 10 metrów jedwabiu ${ }^{37}$.

Wywodziła się od manteau oraz swobodnych dezabilek. Początkowo była to luźna suknia, noszona na gorset i obszerną spódnicę, z podwójnymi dwustronnymi fałdami, które na plecach swobodnie spływały z ramion od prostej linii dekoltu i wydłużały się w tren, a z przodu zbiegały się w talii, połączone dwiema kokardami ${ }^{38}$.

W latach czterdziestych górną część sukni bardziej dopasowano za pomocą podszewki z mocniejszego płótna, która była sznurowana z tyłu sukni pod fałdami, a także dzięki zaszyciu fałd od ramion do 1/3 długości pleców. Na skutek otwartego przodu, widoczna była spodnia spódnica. Wykonana z gładkiego pikowanego jedwabiu, a w dwornej wersji z tej samej tkaniny co właściwa suknia, często bogato zdobiona haftami, galonami, wstążkami czy kwiatami. Suknia opadała na owalną rogówkę.

W sukni w stylu francuskim stanik był przylegający do ciała, otwarty, z głębokim dekoltem w kształcie litery „V”. Fałdy na przodzie były ozdobione koronką bądź haftem. Dekolt finezyjnie obszywano wąską falbanką koszuli. Bawet i listwy do wyłogów przeważnie stanowiły komplet. Od lat siedemdziesiątych

\footnotetext{
34 Ł. Gołębiowski, op. cit., s. 221.

35 M. Możdżyńska-Nawotka, op. cit., s. 156.

36 F. Boucher, op. cit., s. 292.

37 M. Możdżyńska-Nawotka, op. cit., s. 157.

38 Ibidem, s. 157.
} 


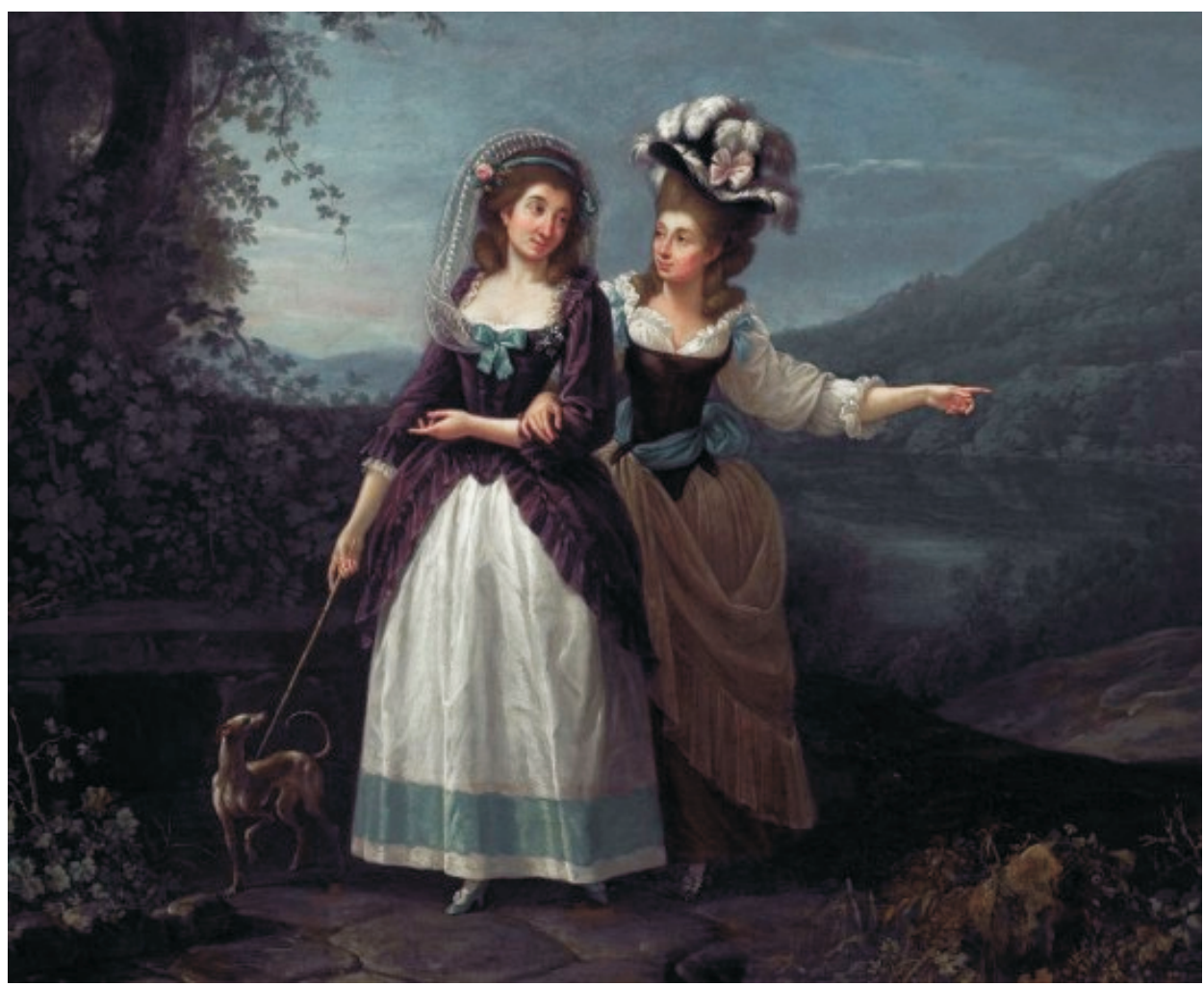

Portret Aleksandry i Izabeli Potockich (mal. Carlo Labruzzi, 1779-1780, ol., pł., nr inw. Wil.1691, numer fotografii: C11917, fot. Zbigniew Reszka), Muzeum Pałacu Króla Jana III w Wilanowie. Za zgodą Muzeum Pałacu Króla Jana III w Wilanowie. 
bawet powoli wychodził z mody, ponieważ coraz powszechniej noszono suknie z rozciętą z przodu spódnicą, a brzegi stanika schodziły się na środku ${ }^{39}$.

Widoczną rewolucję w formie przeszły rękawy sukni. Pierwotnie sięgały do łokci i wszywano je do wyciętej wysoko pachy. Ich kształt przypominał dzwon, gdyż rozszerzały się u dołu i były zakończone mankietem. Od połowy XVIII wieku pożegnano się z mankietami, a zaczęto stosować podwójną lub potrójną rozkloszowaną falbanę, która od strony wewnętrznej była węższa. Efektowne angażanty przyszywano od środka do falbany. „Rękawy sukien zdobione były angażantami, czyli muślinowymi czy koronkowymi mankietami, nieraz aż potrójnymi" ${ }^{40}$. W latach siedemdziesiątych XVIII wieku wyszły z mody owe falbany, które zostały zastąpione przez proste rękawy, długości trzy czwarte i upiększone cienkimi riuszkami ${ }^{41}$.

Pod koniec lat siedemdziesiątych XVIII wieku dzięki elegantkom angielskim, które zmęczone były wystawnością sukien w stylu francuskim, wprowadzono na rynek modowy robe à la anglaise. Suknie à la française pozostawały zarezerwowane jedynie na dworskie ceremonie, a na co dzień noszono suknie à l'anglaise. Damy porzuciły pompatyczne kreacje i zainteresowały się prostszymi, swobodniejszymi i wygodniejszymi angielskimi sukniami. Stosownie ujął to Gołębiowski:

zrzucono wszystko, co dziwaczne, przesadne i wymuszone, a zbliżyć się do pięknej natury ośmielono, do wspaniałych starożytności wzorów. Zniknęły (...) robrony, szusty, rogówki i tem podobne, owe niebotyczne fryzury, krępowanie ciała z uszkodzeniem zdrowia nie raz $^{42}$.

Moda angielska charakteryzowała się mniejszym przepychem niż francuska. Nowa moda podkreślała wdzięk i urodę, a wcześniejsza moda paryska lansowała pozycję i prestiż. Z czasem odrzucono sztywne zasady ubioru i życia towarzyskiego.

Kobiece ciało modnie „deformował” nowy, skrócony gorset, który nie ściskał całej klatki piersiowej tylko samą talię. Przeciwwagą dla podkreślonego z przodu biustu było przywiązanie pod spódnicą poduszki bądź wałka w celu uniesienia tyłu sukni. Ten rodzaj sukni szyto z drukowanych indyjskich bawełnianych tkanin lub cienkich jedwabi. $\mathrm{Z}$ jednego kawałka tkaniny krojono środek tyłu wraz ze spódnicą. Od góry do linii stanu tkaninę układano w fałdy i dalej puszczano swobodnie. Do stanika na bokach przyszywano spódnicę ułożoną w miękkie fałdy ${ }^{43}$.

39 Ibidem, s. 157.

40 I. Turnau, Ubiór narodowy $w$ dawnej Rzeczypospolitej, Warszawa 1991, s. 61.

41 M. Możdżyńska-Nawotko, op. cit., s. 160.

42 Ł. Gołębiowski, op. cit., s. 64.

43 M. Możdżyńska-Nawotko, op. cit., s. 164. 


\section{Robe à la polonaise}

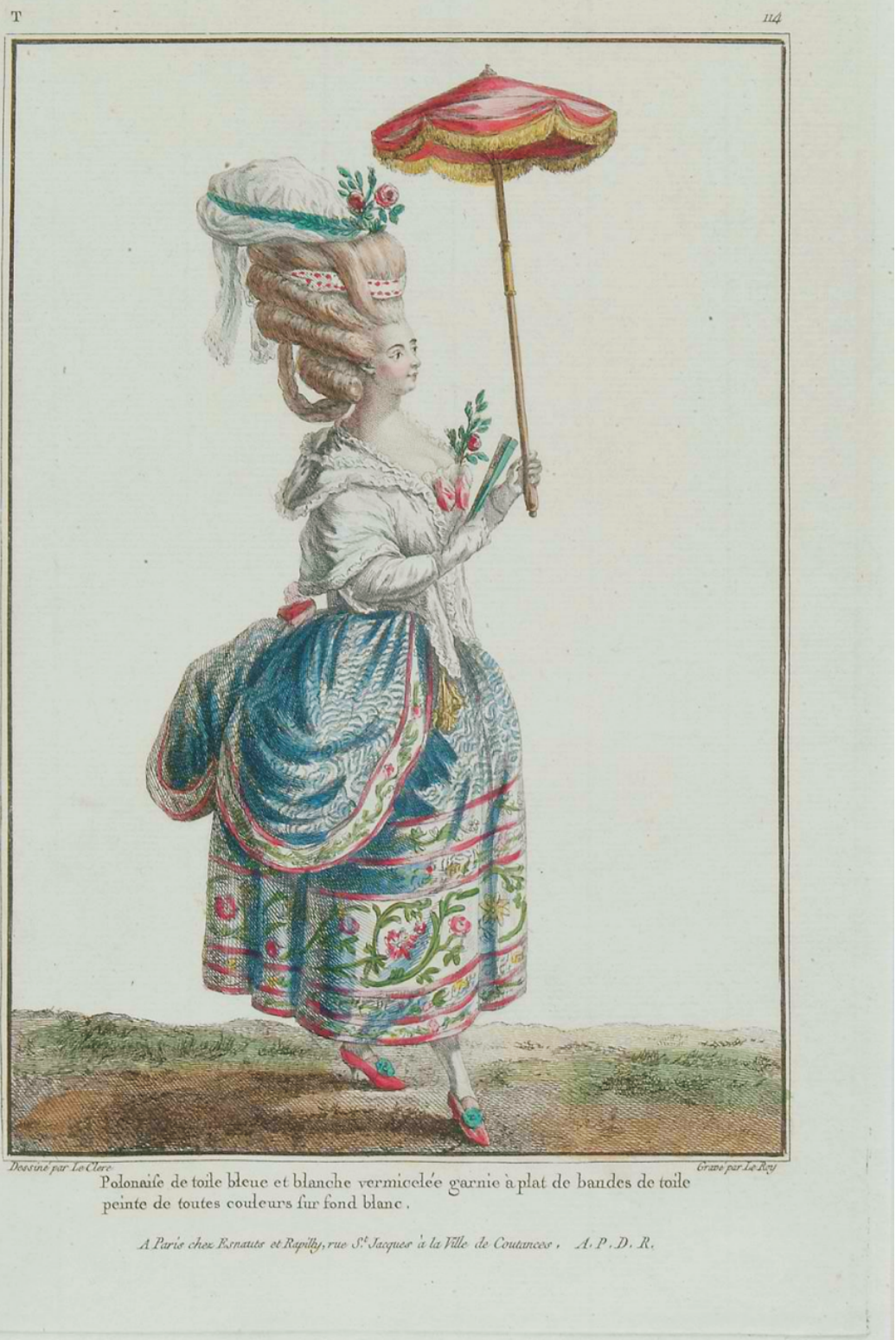

Dama $w$ błękitnej polonezce z czerwona parasolka (Le Clerc, Pierre Thomas, 1778-1787), Muzeum Narodowe w Warszawie. Za zgodą Muzeum Narodowego w Warszawie. 
Młode arystokratki chętnie nosiły jedwabne suknie w modne paski i desenie kwiatowe o jasnych kolorach. Krojono je bez odcinania w stanie, wszywano długie, wąskie rękawy, a stanik był dopasowany i trochę usztywniony, sznurowany z tyłu. Całość prezentowała się lekko i dziewczęco.

Do ostatniej dekady XVIII wieku dużą popularnością cieszyła się suknia zwana poloneska. Była inspirowana robe à la française i narodowym strojem kobiecym. Mimo iż była niezwykle popularna wśród polskich dam, to jej geneza wywodziła się z Francji. Jak pisał Gołębiowski był to „gatunek damskiej sukni narodowej na pozór, nie u nas wszakże wynalezionej, lecz od Francuzów przejętej" "44. Charakterystyczną cechą poloneski było drapowanie w potrójny feston oraz stosunkowo krótka spódnica. Podpięcie miało zastosowanie praktyczne, gdyż chroniło suknię przed zabrudzeniem. Suknia była otwarta na przodzie z dopasowanym, gładkim stanikiem. Kreację uzupełniały piękne falbanki, zawsze namarszczone wzdłuż środka sukni. Narzutki do polonaise miały niekiedy doszyte kapturki ${ }^{45}$. Uzupełnieniem efektownej sukni był słomkowy kapelusz i parasolka. Zainteresowanie sielankowym wiejskim życiem spowodowało zmiany w modzie kobiecej. Powstały kostiumy wzorowane na ubiorach ogrodniczek i pasterek. Elegantki z chęcią nakładały ten lekki rodzaj sukni na uroczystości takie, jak festyny czy pikniki dworskie.

Około 1780 roku w szafach majętnych dam znalazły się chemise, czyli suknie pochodzące od dezabilu. Ta suknia diametralnie różniła się od wcześniejszych wymyślnych modeli. Wkładano ją przez głowę lub przez nogi, a jedyną jej ozdobą były falbanki przy głębokim dekolcie i u dołu rękawów oraz kolorowa szarfa $\mathrm{z}$ jedwabiu do przewiązania się $\mathrm{w}$ pasie. Suknia ta $\mathrm{w}$ formie pomarszczonej koszulki z rękawami sięgającymi do łokcia nie była odcinana w pasie. Wykonana była z lekkich, białych tkanin takich, jak: muślin czy bawełna. „Krojona $\mathrm{z}$ całości i ściągana przy szyi sznureczkiem, chemise stanowiła radykalne zerwanie z obowiązującą modą dopasowanych sukni, składających się z osobno wymodelowanych części. (...) Charakterystyczny dla lat 80 . i początku 90 . był owalny dekolt wykończony falbaną"46.

W latach osiemdziesiątych nadeszła moda na tzw. lewitki - suknie otwarte z przodu. Krojono je bez odcinania w pasie. Fałdy na plecach były zaszyte, a dołem rozszerzały się i przechodziły w tren. Pod spód lewitki wkładano stanik przypominający gorsecik z krótkimi rękawami. „(...) lewitki były sukniami o płaszczowym kroju, otwarte od pasa dla ukazania spódnicy, wąskich, długich rękawach, trenie i ozdobach pasmanteryjnych. Jako suknie mniej strojne od robronów i polonesek" $"$.

\footnotetext{
44 Ł. Gołębiowski, op. cit., s. 213.

45 E. Szyller, op. cit., s. 168.

46 M. Możdżyńska-Nawotka, op. cit., s. 167.

47 Historia kultury materialnej Polski w zarysie, op. cit., s. 351.
} 
Zauroczenie starożytnymi wykopaliskami i neoklasycyzmem znalazło odzwierciedlenie w strojach. Tak zwane ,greczynki”, czyli płaszczyki obszyte futrem i ozdobione u dołu motywami meandra, stały się modne pod koniec XVIII wieku. „Modne damy warszawskie (...) przebrały się pośpiesznie za Rzymianki czy Greczynki w białe suknie z wysokim stanem, barwne szale indyjskie i płaskie pantofelki”"48. Popularnością cieszyły się też tkaniny w paski, mające symbolikę wolnościową inspirowaną amerykańską flagą ${ }^{49}$.

W XVIII wieku można wyróżnić dwa dominujące style. Na początku „krzykiem mody" były bogato zdobione suknie z licznymi falbankami, koronkami, rogówkami i ozdobami. Przeznaczano na nie duże ilości tkaniny. Ten rodzaj sukni podkreślał biust i wąską talię oraz szerokie biodra. Mimo że suknia prezentowała się okazale, była bardzo niewygodna, krępowała ruchy i ze względu na zbyt obcisły gorset szkodziła zdrowiu.

$\mathrm{W}$ miarę upływu lat moda przechodziła przeobrażenia i podążała w kierunku wygody i prostoty. Zrezygnowano ze strojnych i ciężkich sukien na rzecz lekkich i zwiewnych. Nową modę oceniano pozytywnie za umiarkowanie w ilości zużytych tkanin przeznaczonych na uszycie sukni i rozsądne dobieranie dodatków. Rosnące tempo zmian w zawartości garderoby i szybsze zużywanie się ubiorów mogło negatywnie wpływać na budżet rodzinny.

\section{Moda rekreacyjna}

W XVIII wieku ludzie znali mało sposobów na spędzanie wolnego czasu. Uprawianie sportów należało do dziedzin, które dopiero zaczynały „raczkować”. Dyscypliny sportowe cieszące się dużą popularnością to jazda konna, polowania, a zimą jazda na łyżwach. Oczywiście, każdy z tych sportów wymagał specjalnego ubioru. Szlachetnie urodzone damy z entuzjazmem oddawały się naukom jazdy konnej czy polowania. W pierwszej połowie XVIII wieku odzież sportowa pozostawała pod wpływem mody francuskiej. W drugiej połowie wieku wielbicielki sportów wzorowały się już na ubiorach dam angielskich.

W Anglii podobnie jak we Francji i we wszystkich krajach Europy Zachodniej, ubiory zmieniały się wraz ze zmianami obyczajowości. Jednak do powszechnej wówczas dbałości o wygodę Anglia dodała pewną purytańską powściągliwość oraz wprowadziła stroje sportowe. Istotną rolę odegrało też upodobanie do życia wiejskiego, zamiłowanie do polowania oraz gier i zabaw na świeżym powietrzu ${ }^{50}$.

\footnotetext{
48 A. Bardecka, I. Turnau, op. cit., s. 128.

49 M. Możdżyńska-Nawotka, op. cit., s. 166.

50 F. Boucher, op. cit., s. 290.
} 
Damski strój rekreacyjny nasycony był elementami o męskim charakterze. Zaczęto go nazywać ,amazonką”. Górną część stroju stanowił, wzorowany na męskim szustokorze (kaftan męski sięgający kolan; miał szerokie mankiety i długie rękawy) żakiet, kamizelka i koszula. Dolna natomiast składała się ze spódnicy zapinanej na guziki, pod którą nakładano spodenki do kolan. Dodatkami uzupełniającymi sportową kreację był trójgraniasty kapelusz i buty za kolano. „Zapożyczenia ze stroju męskiego wywarły z kolei wpływ na modę francuską. Strój do konnej jazdy składał się z kaftana, kamizelki i spódnicy, często uzupełniał go koronkowy krawat i trójrożny kapelusz" ${ }^{51}$.

W drugiej połowie XVIII wieku damy miały do dyspozycji dwa fasony „amazonek". Pierwszy wariant stanowiła spódnica do kostek i góra o kroju fraka lub redingote (suknia-płaszcz otwarta na przodzie; miała pelerynkowy kołnierz i długie rękawy). Strój ten panie zakładały do polowań i jazdy konnej. W drugim rodzaju ,amazonki” zmieniła się wyłącznie długość spódnicy, która sięgała nad kostkę. Pod spódnicą ukryte były spodenki, a głowę zdobił kapelusz z piórem. Tak odziane damy mogły wyruszyć na lodowisko i miło spędzić czas ślizgając się na lodzie.

W takim stroju damy nie tylko oddawały się sportowym zabawom, ale równie dobrze mogły go założyć na czas podróży.

\section{Okrycia wierzchnie}

Garderoba polskich dam uzupełniona była okryciami wierzchnimi zależnymi od pory roku i pogody. Do wytwarzania ciepłych peleryn i żakietów wykorzystywano przede wszystkim futra. W letnie dni damy zakładały okrycia z lżejszych tkanin. Ubrania wierzchnie komponowały się z całym strojem elegantek.

\section{Jupka}

W Polsce dużym powodzeniem cieszyły się jupki, które pełniły rolę płaszczyków. Kaftanik ten kobiety zakładały na obficie marszczoną spódnicę. Jupki charakteryzowały się luźniejszym krojem. Były rozszerzone ku dołowi, a ich długość sięgała do bioder. Poły zachodziły na siebie, a końce rękawów były rozkloszowane. Kołnierz jupki mógł być szeroki, wykładany albo mały i stojący.

Na sznurówkę kładły jupeczkę krótką, za stan cokolwiek dłuższą, a rękawami po łokieć krótkimi, z materii takiej jak spódnica albo też i odmiennej, z tyłu fałdzistą, z połami przestronnymi na przodzie (...) jupeczki były w stan wcinane opięto,

51 Ibidem, s. 292. 
na guziki z przodu zapinane, z rękawami do pięści sięgającymi. Do rękawów krótkich (...) przypinały mankiety wielkie, gazowe z koronkami, podwójne; i nie zwały się takie mankiety mankietami, lecz angażantami. Do rękawów długich przypinały mankietki małe bez koronek ${ }^{52}$.

W chłodniejsze dni lub zimą damy zakładały podszywane futrem jupeczki. Niektóre z nich miały ozdobione futrem rękawy i kołnierze. Letnia odmiana tego stroju podszyta była kitajką lub płótnem glancowanym. W ciepłe dni kobiety nic nie zakładały na jupeczki.

Zażywały także damy bogate jupeczek bez rękawów, letnich i zimowych, gronostajami podszytych albo popielicami, albo felpą jedwabną; kroju były takiego jak jupeczki bez stanu, i zwały się takie jupeczki kazakinkami; a gdy się w takie jupeczki stroiły, brały na spód gorseciki materialne, opięte, z rękawami do pięści długimi, wąziuchnymi, do grubości ręki stosowanymi; a na takie kazakinki w zimne czasy kładły kontusiki ${ }^{53}$.

Zakładały też chusty na szyję wykonane z muślinu lub jedwabiu, haftowane złotą i srebrną nitką w kwieciste wzory. Chusty te były różnych kolorów, m.in. białe, zielone, czerwone czy żółte. Końce chusty krzyżowały się na piersiach i przypięte były do jupeczki szpilkami.

Jupki szyto z jedwabi sprowadzanych z Francji bądź z polskich materiałów przeznaczonych na żupany.

Zaletą modnego wówczas ubioru była jego praktyczność i wygoda dzięki luźnemu fasonowi jupki.

\section{Kontusik}

Posiadane informacje na temat kontusików damskich są bardzo skromne. W zbiorach muzealnych próżno szukać oryginalnych kontusików. O tym, jak się wcześniej prezentowały możemy przekonać się oglądając porcelanowe figurki miśnieńskie.

Kontusiki pojawiły się w XVIII wieku i wzorowane były na męskim kroju. Stanowiły narodowy wierzchni strój kobiecy o fasonie kontusza. Początkowe kontusiki były bardzo długie, sięgające do kostek, później stawały się coraz krótsze, niemalże do kolan. „Kontusiki te długie do połowy uda noszono jako cieplejsze okrycie na suknie i jupki. Miały one odrzucane na plecy rękawy, a szyto je na wzór męskiego kontusza" ${ }^{54}$. Podbite futrem z kun, popielic czy soboli zakładane były przez eleganckie damy porą zimową.

\footnotetext{
52 J. Kitowicz, op. cit., s. 263.

53 Ibidem, s. 264

54 I. Turnau, Ubiór narodowy w dawnej Rzeczypospolitej, Warszawa 1991, s. 59.
} 
Dzięki pracy nieocenionego Kitowicza mogę zaprezentować opis kontusika białogłowych:

Zimą na takie jupeczki brały kontusiki futrem podszywane, z długimi rękawami wiszącymi, z wylotami szerokimi, do ręki wytchnięcia sposobnymi, u ramion obszernie sfałdowanymi, u pięści wąsko ścinanymi. Te kontusiki zdejmowały z siebie, przychodząc do ciepłej izby, którymi okrywali się zostawieni za drzwiami lokaje, paziowie, węgrzynkowie i inni służebni, mianowicie na balach i redutach, na których całe noce w przysionkach zimnych pokutować musieli. Której nie stać było na kontusik, obywała się jupeczką samą. Kontusik był długi do wpół udów, trwał długi czas w modzie, choć nastały inne futra ${ }^{55}$.

Do opisanych wyżej kontusików damy wkładały na głowę rogatywki z piórkami.

\section{Salopa}

Modnym okryciem wierzchnim w formnie peleryny była salopa, szczególnie popularna w XVIII i XIX wieku. W Polsce pojawiła się w latach trzydziestych XVIII wieku ${ }^{56}$. Charakteryzowała się dość luźnym krojem, fałdami z tyłu i kapturem. Dzięki zapięciu w stanie odsłaniała przód sukienki. Pierwsze salopy szyto tylko z czarnej kitajki. Kolejne podszyte były futrem i kitajką bądź czerwonym atłasem na jedwabnej wacie, noszone $\mathrm{z}$ zarękawkiem. Początkowo sięgały do kolan, a później nawet do ziemi. Bywały też modne półsalopy - krótkie do pasa, z dłuższymi końcami z przodu i małym kapturkiem. Pólsalopy spotykało się niejednokrotnie $w$ inwentarzach dam polskich, stosowane jako okrycie letnie lub zimowe. Zalety salopy w sposób szczegółowy podkreślał Kitowicz: „Salopa jest suknia bardzo uczciwa i wygodna, najpierwszą ma zaletę od skromności, zasłaniając albowiem całą osobę, ukrywa przed okiem lubieżnym talię, czyli stan, i gors, czyli pierś, dwie pokusy najmocniejsze. (...) może być prędno na osobę włożona"s7.

\section{Caraco}

W drugiej połowie XVIII wieku elegantki lubowały się w wygodnym żakiecie caraco. Nie krępował ich fakt, że pochodził on z szaf francuskich mieszczek. Może był to wyraz zmęczenia dotychczasową niewygodą, jaką zafundował im świat mody. Pojawienie się caraco odzwierciedlało dążenie do większej swobody i prostoty w ubiorze. Przypominało ono górną część sukni w stylu à la

\footnotetext{
55 J. Kitowicz, op. cit., s. 264

56 M. Możdżyńska-Nawotka, op. cit., s. 160.

57 J. Kitowicz, op. cit., s. 266-267.
} 
française lub à la polonaise. Żakiet ten przybierał różne fasony: luźny, z fałdzistym tyłem jak w sukniach o kroju francuskim czy według mody angielskiej dopasowany $\mathrm{w}$ talii, $\mathrm{z}$ kołnierzem, baskiną i długimi rękawami ${ }^{58}$. „Był to dość krótki, zaokrąglony na przodzie kaftanik z kloszową, sutą baskinką i dużym kołnierzem okrągłym lub trójkątnie wykończonym z tyłu" 59 .

Okrycia wierzchnie w mniejszym stopniu ulegały wpływom mody zachodniej niż pozostałe elementy garderoby. Rodzime cechy ubioru polskiego można zaobserwować w tego rodzaju strojach. Ze względu na ostry klimat damy nosiły ciepłe okrycia podbite futrem. Lżejsze płaszcze z jedwabiu elegantki zakładały w letnie dni.

\section{Ozdobne elementy stroju}

Do elementów kobiecego stroju należały: koronki, fichu, bawet, gorset i rogówka. Nadawały kreacjom niepowtarzalnego wdzięku i były odzwierciedleniem charakteru epoki. Podkreślały piękno sukni, a także bogactwo i pozycję właścicielki danej kreacji.

\section{Koronki}

Elementem dekoracyjnym osiemnastowiecznych sukien wytwornych dam były koronki. Odegrały one istotną rolę w modzie rokokowej za czasów saskich i za panowania Stanisława Augusta. Stanowiły symbol elegancji i pozycji społecznej.

Wykonywane z koronek angażanty przypominały swoim kształtem wolanty, którymi obszywano rękawy sukni. Rękaw miał jeden brzeg prosty, a drugi był w kształcie koła. Koronki następnie marszczono i wszywano węższym brzegiem w zakończenie rękawa pod wolantem.

Chusteczki do zakrywania dekoltów, szale jak i wstążki do czepków wykonywano z koronki. Upiększano nią także kobiece koszule i żaboty. We wzorach koronek znalazły się motywy kwiatów i gałązek.

Gołębiowski o koronkach pisał, iż:

(...) Taka ich była mnogość u możnych, tak ważna i kosztowna część wyprawy, że nie tylko mnogie szaty, chustki i ubiorki na głowie były nimi zdobione, ale kaftaniki nocne, koszulka panny młodej, gotowalnia i t.d. Korónkowe noszono palatynki, mantylki, suknie całe (...) Białe i czarne, wedle czasu lub potrzeby, jednostajne i różnowzorzyste, zimowe i letnie, bruxelskie, angielskie i najkosztowniejsze francuskie

58 M. Możdżyńska-Nawotka, op. cit., s. 169.

59 A. Bardecka, I. Turnau, op. cit., s. 128. 
point d'Alençon (...) Bywały jeszcze złote i srebrne korónki do futer, zimowych lub świetniejszych ubiorów ${ }^{60}$.

Koronki były gustownym i pięknym uzupełnieniem damskiej kreacji. Nic więc dziwnego, że modne kobiety wydawały na nie ogromne sumy. „(...) Zofia z Sieniawskich Denhoffowa sprzedała pałac w Warszawie, aby kupić szczególnie piękny zestaw francuskich koronek"61.

Od lat siedemdziesiątych XVIII wieku jakość koronek stopniowo słabła. Zainteresowanie nimi również uległo zmniejszeniu, chociaż nadal było można spotkać wiele kobiet noszących suknie z dodatkiem koronek. Pod koniec lat osiemdziesiątych tego stulecia ostatecznie wyszły z mody. Pozostały jedynie w stroju dworskim jako element dekoracyjny bielizny ${ }^{62}$.

\section{Fichu}

Elegantki chcąc zasłonić głęboki dekolt sukni, osłaniały go przepiękną chustą, tzw. fichu. Ten efektowny dodatek kobiecego ubioru szyty był z jedwabnej gazy lub z cienkiego białego płócienka. Chustę zdobiono haftem z kolorowej jedwabnej przędzy z dodatkiem złotej lub srebrnej nitki. Oprócz tego do zdobienia używano również koronek. Duże chusty krzyżowano na piersiach i wiązano z tyłu w pasie, a mniejsze wiązano z przodu na piersiach albo układano je na ramionach, przeciągając końce przez taśmy na bawecie. Kitowicz następująco wspominał modne wówczas chusty:

Latem (...) kładły chustkę na szyję muślinową, jedwabiem, złotem i srebrem w kwiaty haftowaną, kolorów białego, żółtego, zielonego i czerwonego, której końce, na krzyż na przedzie złożone (...), pierś wypukłą zakrywały, dając przez materią cienką i rzadką dosyć przeźroczystości. Na plecy w miarę łopatek spuszczał się jeden koniec, czyli róg takiej chustki, trzykąt wydający ${ }^{63}$.

\section{Bawet}

Bawet to ozdobna, trójkątna wkładka ostro zakończona lub zaokrąglona $\mathrm{u}$ dołu, wypełniająca wycięcie z przodu sukni. Był on charakterystycznym elementem robe à la française. Niejednokrotnie pod bawetem mieściła się malutka kieszeń. Bawet był niezwykle efektownie wykończony koronkami, haftem,

\footnotetext{
60 Ł. Gołębiowski, op. cit., s. 176-177.

61 M. Możdżyńska-Nawotka, op. cit., s. 162.

62 Ibidem, s. 162.

63 J. Kitowicz, op. cit., s. 263.
} 
drabinką ze wstążek, które po zawiązaniu tworzyły kokardy. Zdarzało się, że zdobiony był nawet drogimi kamieniami. Założenie takiej sukni było bardzo czasochłonne, gdyż za każdym razem bawet musiał być przypinany do kreacji szpilkami. „Przednią część dopasowanego stanika spodniego zakrywał trójkątny bawet, często haftowany wzorzystym jedwabiem lub naszywany koronkami. Zamiast tego stosowano niekiedy na bawecie tzw. echelle ozdobę przypominającą drabinkę z coraz mniejszych koronek" ${ }^{4}$.

\section{Gorset}

Najbardziej kontrowersyjnym elementem stroju był gorset. Przez cały XVIII wiek torturował delikatne kobiece ciała. Gorset (sznurówka) czyli „kaftanik kobiecy do sznurowania, rogami i żelazkami przekładany, męczono je tym sposobem od dzieciństwa, co zdrowiu nader było szkodliwe. Sznurowadłem czyli sznureczkami na krzyż od ramion aż do końca stanu je ściskano"65. Jednakże damy bez sprzeciwu poddawały się modowym katuszom, bo gorset podkreślał dwie najważniejsze pokusy: talię i piersi. „Na wierszch brały sznurówkę rogiem wielorybim, czyli fiszbinem przeszywaną, z wciętym gorsem, ściskając się tymi sznurówkami jak najmocniej dla wydania subtelności stanu, czasem aż do mdłości. Ta sznurówka była powleczona atłasem lub kitajką" ${ }^{66}$.

Gorset ukryty był pod strojną suknią i miał modelować sylwetkę. W dobie rokoka znacznie obniżono górną część gorsetu, by wyeksponować biust. Wypychano go do góry, okrywając odrobiną delikatnej koronki, którą wszywano w dekolt sukni. W celu wyeksponowania biustu wszywano w gorset płaskie listewki z rogowej płytki podniebienia wieloryba. Dzięki nim damska sylwetka stawała się smukła i prosta. Aby tkanina pod wpływem naprężenia nie porozrywała się, brzegi gorsetu obszywano cienką skórką.

Ze względów praktycznych jako podszewkę do jedwabnej sukni stosowano szarą, grubą płócienną tkaninę, która musiała być mocna i wytrzymała na naprężenie wywołane skrępowaniem ciała przez gorset.

Produkcją tak złożonej części damskiej garderoby zajmowali się przeważnie mężczyźni. Wszywanie fiszbinów w twardym materiale wymagało silnej ręki krawców.

Tył gorsetu skrojony był niezwykle wąsko i zachodził wysoko. W ten sposób zmuszał damę do wyprostowania pleców, ściągnięcia do tyłu łopatek i wyprężenia klatki piersiowej. Przód gorsetu wycięty był w kształcie trójkąta, a na biuście wygięty półokrągło. Wokół wycięcia wszywano gruby kawałek fisz-

64 F. Boucher, op. cit., s. 266.

65 Ł. Gołębiowski, op. cit., s. 244.

66 J. Kitowicz, op. cit., s. 263. 
binu. Sznurówka była bardzo twarda, przez co uniemożliwiała wykonywanie skłonu. W XVIII wieku udoskonalono konstrukcję gorsetu. Aby wymodelować tył stożka, wszywano fiszbiny na bokach w kształcie wachlarza, czyli zgodnie z kierunkiem szwów bocznych. Boki gorsetu - nad biodrami rozcinano w patki (kalitki) ${ }^{67}$.

Teoria Veblena odnośnie gorsetu była słuszna. Pisał, że coś tak wymyślnego jak gorset świadczy o bezczynności jego właścicielki. Gorsety były utrudnieniem w życiu codziennym, a także okaleczały ją i zmniejszały energię życiową. Kobiety noszące ten element stroju niezdolne były do jakiejkolwiek pracy. Mimo iż gorset wyrządzał krzywdę fizyczną kobiecie, to jednak był niezbędnym elementem modnej kreacji. Deformację ciała rekompensowało większe uznanie wśród elit ${ }^{68}$.

\section{Rogówka}

Modną sylwetkę kształtowała rogówka, czyli tzw. spódnica - stelaż, która była kolejną niewidoczną częścią garderoby i równie niepraktyczną jak gorset. Elegantki zakładały ją pod spódnicę, aby nadać jej pożądany kształt. Dzięki rogówce tkaniny sukien mogły być odpowiednio zaprezentowane. Pierwsze wzmianki o rogówkach na terenie Polski zanotowano ok. połowy lat trzydziestych XVIII wieku.

Rogówka była niezwykle ekskluzywną częścią damskiej konfekcji. Zdarzało się, że w ramach oszczędności importowane fiszbiny zastępowano wikliną bądź sitowiem. Podobny efekt próbowano osiągnąć przez krochmalenie halek lub wszywanie poduszek na bokach pod suknią.

Rozmiar i kształt rogówki modyfikował się wraz ze zmianami w dziedzinie mody. Uzależniony był od okoliczności, rodzaju tkanin i pozycji społecznej właścicielki. Wczesne formy rogówki charakteryzowały się niewielkimi rozmiarami i kształtem przypominającym stożek lub dzwon. Lata trzydzieste przyczyniły się do „rozrostu” rogówki, a także zmiany kształtu na formę kolistą. Dzięki istotnej różnicy obwodu między następnymi obręczami, spódnica przybiera kształt zbliżony do kopuły, której obwód u dołu wynosi 3,5 metra. W kolejnych latach obręcze miały kształt owalny ${ }^{69}$. Pamiętnikarz Kitowicz tak przedstawił swoją definicję rogówki: „Rogówka była to spódnica z płótna, na trzech obręczach z wielorybiej kości obszyta, na jednej w pas, na drugiej w kolano, na trzeciej wpół łydki. Te obręcze nie były okrągłe jak na beczce, ale spłaszczone do podługowatości na kształt wanny owalnej"70.

67 M. Możdżyńska-Nawotka, op. cit., s. 148-149.

68 T. Veblen, Teoria klasy próżniaczej, Warszawa 2008, s. 146.

69 M. Możdżyńska-Nawotka, op. cit., s. 144-145.

70 J. Kitowicz, op. cit., s. 267. 
Okazałe i odstające na bokach spódnice były zdecydowanie nieporęczne. Przeszkadzały damom m.in. w podróży karetą czy podczas odbywających się przy stole spotkań towarzyskich. Obszerne spódnice opadające na rogówki wzdymały się wokół damskich bioder podczas siedzenia, tak że kształtem przypominały balon. Na bokach unosiły się niezwykle wysoko i niejednokrotnie stanowiły zagrożenie dla współtowarzyszy biesiady ${ }^{71}$.

W połowie XVIII wieku pojawia się wygodniejszy model rogówki. Dwa półokrągłe stelaże połączone zostały ze sobą taśmą i przywiązane były w talii. W ten sposób zostały powiększone kobiece biodra. W latach sześćdziesiątych rogówki wciąż były pokaźne i nader popularne wśród majętnych kobiet.

$\mathrm{Z}$ początku żadna dama na publicznym widoku nie pokazała się bez rogówki, nawet i w domu przy gościu. Potem zaczęli brać rogówki tylko na wielkie publiki, na kompanie, na bale, a nareszcie ku ostatnim latom panowania Augusta III te gmachy zawadzające w cale zostały zarzucone, wyjąwszy dni galowe niektóre u dworu, do całowania ręki królewskiej damom senatorskim przeznaczone; w takie dni prezentowały się damy królowi w robach, a zatem na rogówkach ${ }^{72}$.

Rogówki osiągnęły największe rozmiary w latach siedemdziesiątych. Być może chciano dopasować suknie do wielkości noszonych fryzur. Wielkość rogówek zmniejszyła się dopiero w latach osiemdziesiątych, a pod koniec dekady zastąpiły je wałki, które przywiązywano na biodrach ${ }^{73}$.

Rozłożysta rogówka, mimo iż na portretach wyglądała zjawiskowo, to powodowała fizyczny dystans między damą a otoczeniem. Świadczyła o wysokim stanie społecznym swojej właścicielki. Istotne było poruszanie się w rogówce. Bagatela, nawet przejście przez wąskie drzwi czy usadowienie się na krześle wprawiało w zakłopotanie niejedną damę. Każda elegantka musiała zaprezentować się w niewygodnej sukni z gracją i niewymuszoną swobodą.

Wspomniane elementy stroju należały do niezwykle kosztownych. Najdroższym z nich były koronki, którymi obszywano różne część stroju. Ale nie tylko przepiękne koronki przyciągały wzrok, również fantazyjne zdobione bawety. Te dodatki nadawały sukniom charakterystycznego piękna. Po wymienionych elementach ubrania można obecnie datować czas jego powstania.

\section{Dodatki do stroju}

W XVIII wieku, tak jak i obecnie, kobiety zwracały szczególną uwagę na dodatki do ubioru. Dla zaspokojenia własnych zachcianek, polskie elegantki nie

71 M. Możdżyńska-Nawotka, op. cit., s. 145.

72 J. Kitowicz, op. cit., s. 267.

73 M. Możdżyńska-Nawotka, op. cit., s. 145, 148. 
przejmując się kosztami, wydawały duże sumy pieniędzy na modne i drogie dodatki do stroju. Charakterystyczną cechą omawianego okresu jest ich cały wachlarz. Na rynku coraz częściej pojawiały się wyroby gotowej konfekcji. Były to drobne akcesoria stroju: kapelusze, czepki, pończochy, rękawice, wstążki, koronki i wyroby pasamoniczne.

\section{Trzewiki}

Buty były niezbędnym elementem stroju. Interesujące, że w XVIII wieku nie było rozróżnienia na but prawy i lewy. Oba wykonywano według jednej formy. Trzewiki do codziennego użytku wykonywano z białej lub kolorowej skóry. Na eleganckie wyjścia zakładano jedwabne pantofelki. Na ich przodzie znajdowały się patki, które zapinano na rozmaite klamerki - kwadratowe bądź owalne, srebrne lub stalowe, często wysadzane kamieniami. Sporadycznie podbicie damskiego trzewika było zdobione haftem. Na początku wieku, obcasy były delikatne i smukłe, później przybrały postać bardziej masywną. Materiałem, z którego powstawał obcas było drewno. Wygięcie obcasa ku środkowi optycznie zmniejszało stopę damy, a także wzmacniało konstrukcję trzewika, co pomagało utrzymać równowagę. Obcasy pantofelków, jak również laczków bez pięt umieszczone pomiędzy podeszwą a piętą, ewidentnie nie ułatwiały chodzenia ${ }^{74}$.

W latach rządów Augusta III popularne były trzewiki z cienkiej skórki, malowanej w kwiaty. Jedwabnymi wstążkami zawiązywano klapki na przodzie pantofelka. Następnie pojawiła się moda na zamszowe, czarne trzewiki upiększone srebrnym lub złotym haftem. Około 1750 roku przyszedł czas na trzewiki bławatne, atłasowe i grodeturowe różnych kolorów. Były one gładkie, bez ozdobnych haftów, zapinane na srebrną sprzączkę. „Majętna płeć, która przedtem obyła się, mówiąc o jednej osobie, czterma parami trzewików skórzanych na rok, do obmycia i ochędożenia sposobnych, potem potrzebowała co miesiąc, a wymyślniejsza co tydzień inszych, bo lada plamka na trzewiku bławatnym zrobiona już go z garderoby pani rugowała"75. Dużym powodzeniem cieszyły się trzewiki paryskie, ale także warszawskie należały do tych pożądanych. Kupowane były dla żony lub narzeczonej jako prezenty.

Damy po domu nosiły mulety, czyli pantofelki bez pięt, ale na obcasie. Pod koniec XVIII wieku w związku ze zmieniającą się modą, która teraz przybrała linię prostszą i bliższą budowie ciała, popularne stały się buciki o szpiczastym nosku, na niziutkim obcasie. Ustąpiły one miejsca miękkim, atłasowym pantofelkom nieposiadającym obcasa. Obuwie to należało do niepraktycznych, gdyż

74 F. Boucher, op. cit., s. 281.

75 J. Kitowicz, op. cit., s. 266. 
było narażone na zabrudzenie i szybkie zniszczenie. Wobec tego w wyprawach ślubnych znajdowało się po kilka par takich pantofelków.

\section{Pończochy}

Znaczną uwagę przywiązywano do pończoch. Elegantki nosiły pończochy sprowadzane z zagranicy, m.in. bawełniane weneckie, a także pończochy angielskie. Towarem ekskluzywnym były pończochy półjedwabne i jedwabne.

Pończochy wełniane zakładano porą zimową. Farbowano je na rozmaite kolory. W bogatszych domach noszono także pończochy kastorowe $\mathrm{z}$ bobrowej sierści. W letnich miesiącach na nogach szlachcianek prezentowały się pończochy niciane, tudzież z cienkiej dzianiny jedwabnej. W końcu XVIII wieku przyszła moda na poloneskę, która odsłaniała nogę powyżej kostki. Był to dobry czas dla pończoch, które mogły przybierać kolor sukni lub były białe czy pastelowe ${ }^{76}$. Gustowano w szczupłych łydkach, więc osiemnastowieczne damy zakładały pończochy jak najcieńsze - jedwabne lub niciane nawet w porze zimowej. W takiej delikatnej i cieniutkiej pończosze „,wydaje się noga subtelniejsza; i choć w mróz dokucza zimno, ale za to nadgradza ukontentowanie, jakie znajduje dama w swojej sarniej nodze, choć to nieprawda, kiedy niejedna, lubo w jedwabnej pończosze, ma giczały grube jak stępory"77. Tak sarkastycznie ówczesną modę pończoszaną przedstawił nam Kitowicz.

Pończochy podtrzymywano podwiązkami zaraz nad kolanem. Najpierw wykonane były one ze wstążek, które zawiązywano, a następnie pojawiły się podwiązki z galonów złotych lub srebrnych, zapinanych na sprzączkę brylantową lub perłową, do kompletu z klamerką trzewika. Wartościowe klamerki podwiązek były zdobyczą dworskich łotrzyków, którzy pod pozorem zalotów wyłudzali je od infantylnych panien. Na rynku pończoszanym pojawiły się francuskie podwiązki w formie obszytej atłasem bransoletki z wszytą sprężynką, która działała jak guma ${ }^{78}$.

\section{Wachlarz}

Wytwornym atrybutem stroju każdej modnej damy był wachlarz. Był nie tylko fashionerskim dodatkiem, który świadczył o statusie społecznym, ale również pomocny w kontaktach towarzyskich. Uchodził za symbol kokieterii, gdyż to właśnie w XVIII wieku obserwujemy rozkwit „sekretnego języka wachlarza", którym ówczesne kobiety z wyższych sfer mogły kokietować i uwodzić mężczyzn.

76 M. Możdżyńska-Nawotka, op. cit., s. 174.

77 J. Kitowicz, op. cit., s. 265.

78 M. Możdżyńska-Nawotka, op. cit., s. 175. 
Do Polski importowano wachlarze z Francji i Dalekiego Wschodu. Ten dodatek był nieodłącznym elementem stroju każdej elegantki. Zabierały go do teatru czy kościoła. Stanowił luksusowy podarunek od mężczyzny, który wypadało przyjąć.

Bez wachlarza nigdy nie były w drodze i na przechadzce, a nawet $i \mathrm{w}$ domach zasłaniały się nim od słońca $\mathrm{i}$ chłodziły powiewaniem onego, kiedy były tańcem lub inna jaką agitacją zmordowane. Wachlarz najmodniejszy był i najdroższy, który miał żebra z słoniowej kości kitajką, malowaniem chińskim ozdobioną, powleczone. Podlejsze wachlarze były z drewna i z papieru z malowidłem, czyli drukiem albo wybijaniem różnych figur i kwiatów ${ }^{79}$.

Wachlarze osiemnastowieczne można określić mianem „dzieł sztuki”. Były produkowane z rozmaitych materiałów, m.in. z kości słoniowej, szylkretu, macicy perłowej, rzeźbionego i malowanego laką. Pokrycie wachlarza wykonywano z cienkiej skórki, tzw. łabędziej lub papieru, które ozdabiano scenami rodzajowymi czy pejzażowymi.

\section{Rękawiczki}

Kolejnym strojnym dodatkiem do ubioru eleganckich pań były rękawiczki. Szyto je ze skóry lub z tkaniny, z której wykonany był strój. Noszono je długie do łokcia, ponieważ rękawy sukni nie zasłaniały przedramienia. Rękawiczki były bez czterech palców, z trójkątną klapką, zdobioną jedwabnym, srebrnym albo złotym haftem. Modne były również mitynki, tj. rękawiczki bez palców z czarnej dzianiny jedwabnej.

Na ręce kładły rękawiczki irchowe, po łokieć długie, palczaste albo też bez czterech palców, klapką, jedwabiem i złotem lub srebrem wyszywaną, przykrywanych, o jednym paluchu, wpółpalca krótkim, na wielki palec. Te rękawiczki były w różnych kolorach, częstokroć do koloru sukni stosowane. Drugiego gatunku używały rękawiczek jedwabnych czarnych, kształtem siatki albo pończochy dzierzganych; te zawsze były o jednym palcu, z klapką bez wyszywania na inne cztery palce spadającą, i zwały się takie rękawiczki-mitynki; lepiej by je było nazywać „nitynkami”, od nici, z których były robione ${ }^{80}$.

Oczywiście, rękawiczki musiały współgrać z kolorem noszonej kreacji. Pod koniec tego stulecia popularność zyskały tzw. mufki. Można było w nich schować różne drobiazgi takie, jak chusteczkę czy wachlarz, a także ogrzać dłonie w czasie mroźnej zimy. „W zimie ręce chroniły wchodzące właśnie w modę mufki,

79 J. Kitowicz, op. cit., s. 265.

80 Ibidem, s. 265. 
rękawy czy zarękawki, uszyte z barwnych jedwabi, wyściełane kosmatą felpą, puchem i bramowane futrem" 81 .

\section{Biżuteria}

Osiemnastowieczne elegantki z zamiłowaniem nosiły biżuterię, która była uzupełnieniem każdej kreacji. Rozkochane w niej były majętne damy. Głowę przystrajały koronami wysadzanymi brylantami, a szyję złotymi krzyżami ozdobionymi cennymi kamieniami ${ }^{82}$. Kosztownym dodatkiem były perły i złote łańcuchy. Wszystkie naszyjniki ozdabiające dekolt nazywano kanakami. Do naszyjników dobierano pasujące manele, czyli bransolety. Modne wówczas bransolety perłowe noszono parami. Dłonie zdobiły pierścienie z szafirowymi drogimi kamieniami przycinanymi w przeróżne kształty. Pierścienie posiadały oczka w kształcie serca, gwiazdki, róży, gołębia. Damy obficie stroiły swoje dłonie pierścionkami, zakładając często po dwa i trzy na jeden palec. Uszy strojono specjalnymi ozdobami ze złota, pereł i szlachetnych kamieni. Lekkie ozdoby to trzęsidła, a ciężkie zausznice. Przybierały one rozmaite kształty i wielkości. Noszono ozdoby koliste, w kształcie półksiężyców albo kwiatów. Kitowicz w sposób następujący opisuje wykończenie osiemnastowiecznego stroju kobiecego:

Szyję zdobiły najprzód koralami, potem koralami z perłami przeplatanymi, potem samymi perłami, potem łańcuszkami złotymi, na ostatku wąską aksamitką czarną, od której spadał między piersi misternej roboty krzyżyk diamentowy lub inny jaki portrecik kamelizowany, albo też bez żadnej figury drogi kamień świecący. Jakie zaś było noszenie na szyi, takie być musiały manele na ręku; pierścionków zaś im więcej na palcach, tym lepiej ręka ubrana. Do uszów przypinały najprzód zauszniczki małe perłowe lub rubinkowe; $w$ złoto oprawne, potem większe w figurę róży z brylantów prawdziwych albo czeskich; te dwa gatunki przetykały przez brzusiec ucha, szpilką za młodu przekłutego. Na ostatek wymyślili zausznice wielkie jak grona winne wiszące z pereł i brylantów, które że uszy przerywały, przeto nie przez ucho, ale za ucho na stronie mocnej bywały zakładane ${ }^{83}$.

Koniecznym dodatkiem były też małe zegarki zwane pektoralikami. Nosiły je damy na szyi lub w kieszeni sukni. Następnym niezbędnym drobiazgiem była tabakierka i ozdobna chusteczka do nosa, pachnąca lawendą ${ }^{84}$.

\footnotetext{
81 A. Bardecka, I. Turnau, op. cit., s. 127.

82 Z. Kuchowicz, op. cit., s. 236.

83 J. Kitowicz, op. cit., s. 264.

84 A. Bardecka, I. Turnau, op. cit., s. 127.
} 


\section{Torebki}

Do przechowywania niezbędnych drobiazgów służyły specjalne kieszenie ukryte pod spódnicą. Mocowano je tasiemkami wokół talii. Były szyte z lnianych lub bawełnianych tkanin. Przez specjalne rozcięcia po bokach spódnicy wkładano rękę do owej kieszeni. Nieodzowny był również woreczek przeznaczony na pieniądze i rozmaite damskie drobiazgi toaletowe. Szyto go $\mathrm{z}$ haftowanych tkanin jedwabnych, dopasowanych kolorystycznie do sukni. Woreczek zastąpił obszerne, głębokie kieszenie, umieszczone pod okazałymi spódnicami ${ }^{85}$. Nowoczesne elegantki nosiły przy sobie płaskie portfele ze skóry bądź jedwabiu wyszywane haftem. Torebki to typ dodatku, który bardzo późno zagościł w kobiecej garderobie. Pojawiły się one na początku XIX wieku wraz ze zmianą fasonu sukni, pod którą nie było już miejsca na kieszenie.

\section{Nakrycie głowy}

Ważnym elementem uzupełniającym strój elegantki było nakrycie głowy. Na początku XVIII wieku noszono niewielkie koronkowe czepki. „Mężatki i wdowy ze swojej strony zaczęły zarzucać dawne czepce, jedynie starsze, nie dbające już o modę, pozostały przy dawnym zwyczaju. Ale to wszystko działo się tylko

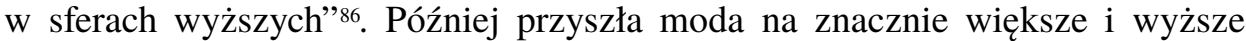
czepce. Wykonane były one z batystu bądź koronki, a zdobiono je wstążkami, piórami lub bukiecikami kwiatów. Nazywano je bonnetami od nazwy tkaniny, z której je wykonywano.

Miejsce czepców zastąpiły kornety. Ich kształt jest ciężko sprecyzować, gdyż zmieniał się w zaskakującym tempie. „Zawisł zaś na rozmaitym składaniu, fałdowaniu, strzępieniu, wykrawaniu, bryzowaniu muślinu, rąbku, koronek i wstążek" ${ }^{87}$. Pierwsze kornety były dwoiste, tzn. żółty był pod spodem, a drugi biały na wierzchu. Damy nosiły kornety na dwa sposoby: opuszczone na policzki i zawiązywane wstążką pod szyją, a innym razem zawinięte w górę. Zimą zakładano kornet $\mathrm{z}$ aksamitu czarnego, podszytego karmazynowym albo różowym atłasem bądź kitajką.

Ten duet był dwojaki: najpierw był szczupły, wierszch głowy i skronie z uchem przykrywający. Potem nastał duet wielki, szeroki, okrywający całą głowę, cały kark i występujący nad twarz na dobrą dłoń, tak iż w takowym duecie pod gębą podwiązanym wydawała się twarz jak w głębokim pudle ${ }^{88}$.

85 Ibidem, s. 127.

86 J. S. Bystroń, Dzieje obyczajów w dawnej Polsce; wiek XVI-XVIII, t. 2, Warszawa 1976, s. 470.

87 J. Kitowicz, op. cit., s. 262.

88 Ibidem, s. 262. 
Potem głowy elegantek zdobiły aksamitne kołpaczki w kolorze zieleni i pąsowe z opuszką sobolą. Następnie powróciła moda na olbrzymie kornety umocowane na stelażu z drutu. Z zagranicznych podróży przywożono kornety tiulowe. Ceny tego okrycia głowy wahały się w granicach od 20 złotych do 6 dukatów, chociaż ich rzeczywista wartość wynosiła mniej niż 10 złotych ${ }^{89}$.

W słoneczne dni panie chroniły głowę i twarz zasłonkami z czarnej lub białej gazy tudzież tiulu, zwanymi kwefami. Dama bez przeszkód mogła dobrze wszystko widzieć i być widziana. Dzięki tej „siateczce” unikały niechcianej i wówczas niemodnej opalenizny.

Dzięki modzie angielskiej pod koniec XVIII wieku pojawiły się kapelusze przystrajane wstążkami, cekinami lub bajorkiem.

(...) zaczęły być modne przy końcu stulecia duże kapelusze oblekane tkaniną, na sztywnej formie, zdobione wstążkami, tiulem w muszki, piórami oraz kapelusze słomkowe i ,łykowe”, opasane i lamowane na brzegach wstążkami w jasnych barwach, noszone do muślinowych sukien „koszulek”

Również ze schyłkiem tego wieku do sukien wzorowanych na strojach orientalnych wprowadzono jedwabne zawoje, upinane na słomianym podkładzie $w$ formie czapeczki i ozdobione egretami z czaplich piór ${ }^{91}$.

Kosztowny i efektowny strój wymagał równie eleganckich i drogich dodatków, dlatego majętne damy zaopatrywały się w różnego rodzaju biżuterię i galanterię. Ważniejsze od zdrowia, wygody i samopoczucia było sprostanie wymogom mody.

$* * *$

W swoim opracowaniu starałam się ukazać piękno i oryginalność strojów osiemnastowiecznych dam. Poświęcały się one, aby wyglądać olśniewająco i zgodnie z kanonami mody zagranicznej. Suknie były prawdziwymi dziełami sztuki, a ich wyjątkowość podkreślały równie kosztowne i efektowne dodatki. Możliwości ruchu w tego typu sukniach były ograniczone. Dostojny sposób poruszania się dam wynikał nie tylko ze zwyczaju czy pochodzenia, lecz również w znacznej mierze zależał od konstrukcji ubioru. Wyższy status społeczny kobiety można było poznać po tym, czy jej gorset kształtem przypominał idealny stożek i po tym, czy nosiła tę niewygodną suknię z gracją i swobodą. Majętne damy wydawały ogromne sumy na stroje i klejnoty.

Motywem człowieka kupującego drogie ubrania była potrzeba życia na odpowiednim poziomie, potrzeba dostosowania się do panującego zwyczaju czy

89 Ibidem, s. 262

90 M. Gutkowska-Rychlewska, op. cit., s. 699-700.

91 M. Możdżyńska-Nawotka, op. cit., s. 171. 
osiągnięcie standardu elegancji. Kosztowny ubiór świadczył nie tylko o możliwościach finansowych i pozycji społecznej, ale też o bezczynności, o braku wykonywania jakiejś pracy. Można by powiedzieć, że damy w XVIII wieku prowadziły próżniaczy styl życia. Pochłonięte były tylko dbaniem o własny wygląd i rozrywki towarzyskie. Świadomie zgadzały się na niewygodne stroje, aby tylko sprostać wymogom mody. Zostaje pytanie, czy warto było cierpieć dla modnego wyglądu i wydawać krocie na ten cel.

Stroje osiemnastowiecznych elegantek mogą być inspiracją dla kreatorów mody i twórców spektakli teatralnych czy filmowych. Choć suknie były piękne, ale wiadomo, że były niewygodne i szkodziły zdrowiu. Nie warto cierpieć z powodu ubioru i żyć jako „ozdoba domu”.

Reasumując, głównym motywem ubierania się w modne i kosztowne stroje była chęć manifestowania prestiżu i pozycji społecznej. Damy przez swój wysoki status społeczny zobligowane były do interesowania się modą i podążania za nowymi trendami. Słusznie zauważył Veblen, iż popularne stroje i akcesoria modowe były na tyle niewygodne, że okaleczały kobiety i odbierały im zdolność do pracy. Mimo iż wyrządzały krzywdę fizyczną, to z drugiej strony powodowały większy prestiż, wynikający ze słabości i kosztowności właścicielki kreacji. Wspomniany autor trafnie spostrzegł, iż marnotrawstwo i próżnowanie na pokaz przynosi prestiż, ponieważ są one świadectwem pozycji materialnej, a ta gdy jest bardzo wysoka przynosi zaszczyty i dowodzi o sukcesie oraz sile.

Zagłębiając się w tajniki dawniejszej mody i obyczajów można poznać daną epokę, mentalność ludzi i ich sposób życia, co, mam nadzieję, udało mi się ukazać w moim artykule.

\section{The wardrobe of Polish fashionable ladies in the XVIII century}

The article is concerned with the wardrobe of Polish ladies in the XVIII century, presenting fabrics, gowns, sportswear, coats, clothing elements and accessories.

Polish fashionable ladies were highly influenced by French and English patterns. Elegant ladies of the XVIII century could be recognized by wearing corsets and onerous panniers. The XVIII century is characterized by two main fashion trends. At the beginning gowns were richly decorated and made from heavy fabrics. Although they looked showy, they were uncomfortable and unhealthy, due to tight corsets. With time gowns became simpler and more comfortable. Flamboyant and heavy gowns yielded to light and gauzy ones. The new trend in fashion was highly appreciated because of the smaller amount of fabrics indispensable to sew a dress and a reasonable choice of accessories.

Polish ladies' wardrobe was complemented by coats used in accordance with the season and the weather. Coats like jupka (sleeveless tunic), kontusik (winter 
fur-lined coat), salopa (coat with a cape) or caraco were not as heavily influenced by western patterns as the other elements of Polish ladies' wardrobe.

Decorative elements, such as laces, fichu, bavettes, corsets and panniers added to the charm of the ladies who wore them. Costly and showy clothing required elegant and expensive accessories. Polish ladies spent a fortune on booties, stockings, fans, jewelry, bags and hats.

Ostentatiously expensive and fashionable outfits were a sign of wealth and social standing. They constituted a lifelong investment and were inherited by next generations.

Key words: fashion, wardrobe, Polish fashionable ladies, gowns, corsets

\section{Bibliografia}

\section{Źródła}

Gołębiowski Ł., Ubiory w Polszcze od najdawniejszych czasów aż do chwil obecnych, Warszawa 1830.

Kitowicz J., Opis obyczajów za panowania Augusta III, Warszawa 1985.

Schulz F., Podróże Inflantczyka z Rygi do Warszawy, [w:] Polska stanisławowska w oczach cudzoziemców, oprac. W. Zawadzki, t. 2, Warszawa 1963.

Vautrin H., Obserwator w Polsce, [w:] Polska stanisławowska w oczach cudzoziemców, oprac. W. Zawadzki, t. 1, Warszawa 1963.

\section{Literatura}

Bardecka A., Turnau I., Życie codzienne w Warszawie okresu oświecenia, Warszawa 1969.

Boucher F., Historia mody: dzieje ubiorów od czasów prehistorycznych do końca XX wieku, Warszawa 2012.

Bystroń J. S., Dzieje obyczajów w dawnej Polsce; wiek XVI-XVIII, t. 2, Warszawa 1976.

Charewiczowa Ł., Kobieta w dawnej Polsce, Poznań 2002.

Dumanowski J., Świat rzeczy szlachty wielkopolskiej w XVIII w., Toruń 2006.

Elias N., O procesie cywilizacji: analizy socjo- i psychogenetyczne, Warszawa 2011.

Furtak T., Ceny w Gdańsku w latach 1701-1815, Lwów 1935.

Gutkowska-Rychlewska M., Historia ubiorów, Wrocław 1968.

Historia kultury materialnej Polski w zarysie, oprac. zbiorowe pod red. W. Hensla, J. Pazdura, t. 4, Od połowy XVII do końca XVIII wieku, (red.) Z. Kamieńska, B. Baranowski, Wrocław 1978.

Jezierski A., Leszczyńska C., Historia gospodarcza Polski, Warszawa 2003. 
Józefecki J., Manufaktura sukiennicza $w$ Skierniewicach w latach 1786-1795, „Mazowieckie Studia Humanistyczne", 1997, nr 1.

Kolenda-Korczakowa K., Działalność ekonomiczna Anny z Sanguszków Radziwiłłowej - manufaktury hafciarskie w świetle nowych znalezisk, [w:] Dwory magnackie w XVIII wieku. Rola i znaczenie kulturowe, (red.) T. Kostkiewiczowa, A. Roćko, Warszawa 2005.

Kuchowicz Z., Obyczaje staropolskie XVII-XVIII wieku, Lódź 1975.

Kula W., Szkice o manufakturach w Polsce XVIII wieku: 1720-1764, Warszawa 1956.

Możdżyńska-Nawotka M., O modach i strojach, Wrocław 2002.

Sieradzka A., Żony modne: historia mody kobiecej od starożytności do współczesności, Warszawa 1993.

Szyller E., Historia ubiorów, Warszawa 1963.

Turnau I., Rzemiosła włókiennicze, odzieżowe i skórnicze 1655-1795, [w:] Z dziejów rzemiosła warszawskiego, (red.) B. Grochulska, W. Pruss, Warszawa 1983.

Turnau I., Ubiór narodowy w dawnej Rzeczypospolitej, Warszawa 1991.

Turnau I., Zmiany w polskiej produkcji włókienniczej w XVIII wieku, Wrocław 1962.

Veblen T., Teoria klasy próżniaczej, Warszawa 2008.

Zarys historii włókiennictwa na ziemiach polskich do końca XVIII wieku, (red.) J. Kamińska, I. Turnau, Wrocław-Warszawa-Kraków 1966. 